\title{
KARAKTERISTIK MIE KERING TERSUBSTITUSI TEPUNG BUNGKIL KACANG TANAH DENGAN PENAMBAHAN GETAH PEPAYA KERING (Carica Papaya L.) TERHADAP KUALITAS FISIKOKIMIA DAN ORGANOLEPTIK
}

\author{
Elis Tsamrotus Sa'adah ${ }^{1)}$, Nurul Husna ${ }^{1)}$, Wike Adhi Anggono', \\ Endang Isti Suciani ${ }^{1)}$, Rekna Wahyuni ${ }^{1)}$ \\ 1) Program Studi Ilmu dan Teknologi Pangan, Fakultas Pertanian, Universitas Yudharta Pasuruan \\ E-mail: elis.itp@gmail.com
}

\begin{abstract}
Abstrak
Produk mie merupakan makanan yang berbahan dasar tepung terigu yang berasal dari tanaman gandum. Untuk mengurangi impor gandum, pemerintah Indonesia menciptakan program diversifikasi pangan berbasis pangan lokal menuju kedaulatan pangan. Tujuan penelitian yaitu mengetahui berapa penambahan getah buah pepaya kering dan bungkil kacang tanah terbaik pada pembuatan mie kering dilihat dari kualitas fisikokimia, organoleptik, serta fisikokimia dan organoleptik. Penelitian ini menggunakan metode Rancangan Acak Kelompok dengan uji DMRT 5\% dan perlakuan terbaik menggunakan uji indeks efektivitas. Perlakuan terbaik secara fisikokimia ialah penambahan getah pepaya kering sebesar 0,1 gram dalam 100 gram dan substitusi tepung bungkil kacang tanah sebesar 15\% dengan karakteristik sebagai berikut: kadar air 8,45\%; kadar protein 18,056\%; kadar abu 0,382\%; kadar lemak 7,084\%; cooking time 192 detik; cooking loss 9,353\%; daya putus 0,324 N/g. Uji organoleptik adalah penambahan getah pepaya kering sebesar 0.3 gram dalam 100 gram dan substitusi tepung bungkil kacang tanah sebesar 5\% dengan karakteristik sebagai berikut: warna 4,75 (sangat menyukai); rasa 4,5 (menyukai); aroma 4,75 (sangat menyukai); dan tekstur 4,85 (sangat menyukai). Uji fisikokimia dan organoleptik ialah penambahan getah pepaya kering sebesar 0.3 gram dalam 100 gram dan substitusi tepung bungkil kacang tanah sebesar 5\% dengan karakteristik sebagai berikut: kadar air 8,02\%; kadar protein 14,620\%; kadar abu 0,347\%; kadar lemak 3,706\%; cooking time 160 detik; cooking loss 5,628\%; daya putus 0,325 N/g, serta warna 4,75 (sangat menyukai); rasa 4,5 (menyukai); aroma 4,75 (sangat menyukai); dan tekstur 4,85 (sangat menyukai).
\end{abstract}

Kata kunci: enzim papain, tepung bungkil kacang tanah, mie kering

\begin{abstract}
Noodle product is a food made from flour derived from wheat. To reduce wheat imports, the Indonesian government created a program based on local food diversification towards food sovereignty. The aims is knowing how the addition of dried papaya latex and groundnut oilcake's flour best in the manufacture of dry noodles seen from the quality of the physicochemical, organoleptic and physicochemical and organoleptic. This study uses a randomized block design with DMRT 5\% and the best treatment test effectiveness index. The best treatment is physicochemical dried papaya latex is the addition of 0.1 grams in 100 grams and the substitution of groundnut oilcake's flour by 15\% with the following characteristics: water content of $8.45 \%$; protein content $18.056 \%$; ash content $0.382 \%$; fat content $7.084 \%$; cooking time 192 seconds; cooking loss 9.353\%; tensile strength $0.324 \mathrm{~N} / \mathrm{g}$. Organoleptic dried papaya latex is the addition of 0.3 grams in 100 grams and the substitution of groundnut oilcake's flour by $5 \%$ with the following characteristics: color 4.75 (really like); flavor 4.5 (like); aroma 4.75 (really like); and texture 4.85 (really like). Physicochemical and organoleptic was the addition of dried papaya latex by 0.3 grams in 100 grams and the substitution of groundnut oilcake's flour by 5\% with the following characteristics: water content $8.02 \%$; protein content $14.620 \%$; ash content $0.347 \%$; fat content $3.706 \%$; cooking time of 160 seconds; cooking loss 5.628\%; tensile strength $0.325 \mathrm{~N} / \mathrm{g}$, and color 4.75 (really like); flavor 4.5 (like); aroma 4.75 (really like); and texture 4.85 (really like).

Keywords: papain, groundnut oilcake's flour, dried noodle
\end{abstract}




\section{PENDAHULUAN}

Mie adalah salah satu makanan yang sangat digemari semua kalangan masyarakat. Beragamnya kalangan masyarakat ini memicu pola hidup yang bermacam-macam pula. Kecenderungan dan pola hidup masyarakat modern menuntut makanan siap saji. Bahan pangan yang umum dikonsumsi masyarakat sebagai bahan pangan siap saji pengganti nasi adalah mie (Widiatmoko, 2015). Produk mie merupakan makanan yang berbahan dasar tepung terigu yang berasal dari tanaman gandum. Untuk mengurangi impor gandum, pemerintah Indonesia menciptakan program diversifikasi pangan berbasis pangan lokal menuju kedaulatan pangan. Upaya pelaksanaan diversifikasi pangan agar tidak tergantung kepada tepung terigu terus dilakukan, salah satunya adalah penggunaan tepung bungkil kacang tanah sebagai subtitusi tepung terigu dalam pembuatan mie.

Manfaat enzim papain untuk kesehatan adalah dapat digunakan sebagai bahan aktif dalam preparat farmasi seperti untuk obat gangguan pencernaan protein, dispesia, gastritis (peradangan selaput lendir pada lambung), serta obat cacing (Silaban dkk, 2012). Sehingga sangat aktif dan memiliki kemampuan mempercepat proses pencernaan protein. Penambahan getah pepaya kering sebagai sumber enzim papain pada mie diharapkan mampu mengatasi masalah lambung dan gangguan pencernaan seperti buang air besar dan mencegah wasir ketika orang mengkonsumsi mie tersebut tanpa mencari obat yang mahal atau pergi kedokter.

\section{METODE PENELITIAN \\ Waktu dan Tempat Penelitian}

Pelaksanaan penelitian ini dilaksanakan di laboratorium ITP Universitas Yudharta Pasuruan dan laboratorium ITP Universitas Muhammadiyah Malang pada bulan AprilAgustus 2015.

\section{Bahan dan Alat}

Bahan yang digunakan meliputi bahan utama dan bahan pembantu. Bahan utama meliputi tepung bungkil kacang tanah yang diperoleh dari Gadang-Malang, enzim papain kasar serta tepung terigu merk Cakra Kembar.

Alat-alat yang digunakan untuk pembuatan produk mie kering meliputi timbangan analitik, loyang, sendok, noodle maker, panci pengukus, kompor gas, oven, gelas ukur, baskom alumunium, plastik, sendok.

\section{Rancangan Penelitian}

Penelitian ini menggunakan metode Rancangan Acak Kelompok (RAK) 2 faktorial, dimana faktor pertama terdiri dari 3 level (penambahan getah pepaya kering 0,1 gram; 0,2 gram; 0,3 gram) dan faktor kedua terdiri dari 3 level (substitusi tepung bungkil kacang tanah $5 \%, 10 \%, 15 \%)$.

\section{Pelaksanaan Penelitian}

Diagram alir proses pembuatan mie kering dapat dilihat pada Gambar 1

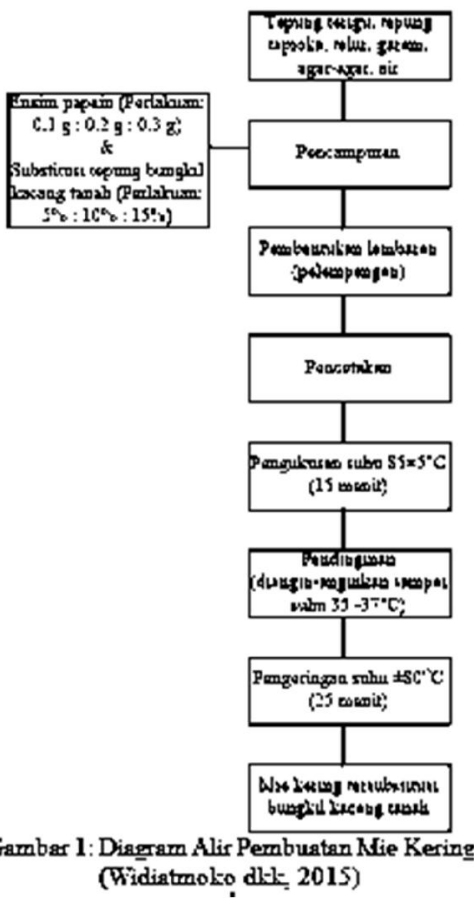

\section{Pengamatan}

Pengamatan dilakukan meliputi analisa fisik, kimiawi dan organoleptik. Analisa Uji fisik meliputi daya putus, cooking time (Oh et al, 1985), cooking loss (Romlah, 1997). Untuk uji kimia meliputi kadar protein dengan metode kjeldahl (AOAC, 1990), kadar abu (Sudarmadji dkk, 1997) dan kadar air (AOAC, 1990 dalam Sudarmadji dkk, 1997), kadar lemak (AOAC, 1990). Sedangkan sifat organoleptik (warna mie masak, rasa mie masak, aroma mie masak, dan tekstur mie masak) diperoleh dari uji organoleptik kesukaan (hedonic) skor menggunakan 20 orang panelis. 


\section{Analisa Data}

Analisa data dilakukan secara ANOVA dengan selang kepercayaan 5\% dan 1\%. Apabila ditemukan pengaruh terhadap salah satu variabel maka dilanjutkan dengan uji DMRT (Duncan's Multiple Range Test). Untuk mengetahui perlakuan terbaik menggunakan metode indeks efektifitas de Garmo et al., (1984) yang dimodifikasi oleh Susrini (2005).

\section{HASIL DAN PEMBAHASAN}

\section{Karakteristik Fisikokimia Cooking time}

Hasil pengamatan terhadap cooking time mie kering akibat substitusi tepung bungkil kacang tanah dan penambahan getah buah pepaya kering berkisar antara $150-200$ detik.

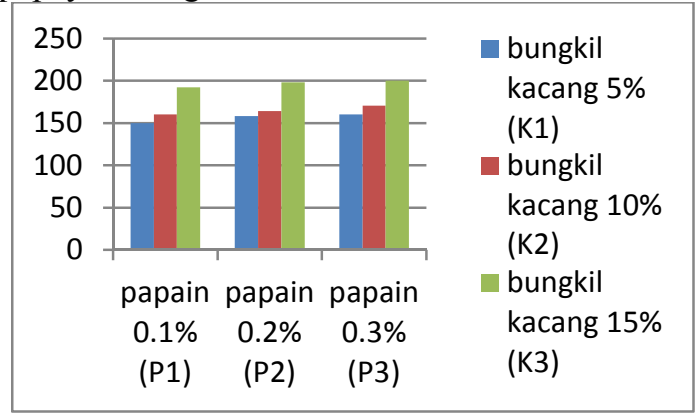

Gambar 2. Rata-rata Cooking Time Mie Kering Akibat Substitusi Tepung Bungkil Kacang Tanah

Gambar 2 menunjukkan bahwa cooking time mie kering cenderung meningkat seiring dengan meningkatnya penambahan tepung bungkil kacang tanah dan enzim papain. Hal ini dikarenakan tepung bungkil kacang tanah memiliki kadar protein yang tinggi sebesar $27.17 \%$ dan kadar lemak yang cukup tinggi pula yaitu $13.9 \%$. Protein dan lemak akan menghalangi penyerapan air ke dalam granula pati. Sehingga waktu gelatinisasi akan terhambat (Muhandri, 2009 dalam Irviani dkk, 2015). Apabila proses gelatinisasi terhambat maka cooking time pun akan semakin lama.

\section{Cooking loss}

Hasil pengamatan terhadap cooking loss mie kering akibat substitusi tepung bungkil kacang tanah dan penambahan getah buah pepaya kering berkisar antara 5,492\%- 9,506\%.

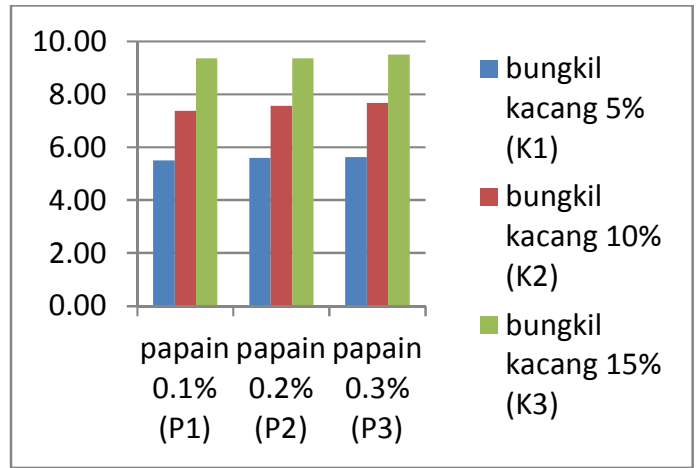

Gambar 3. Rata-rata Cooking Loss Mie Kering Akibat Substitusi Tepung Bungkil Kacang

Tanah

Gambar 3 akan semakin tinggi seiring dengan meningkatnya penambahan tepung bungkil kacang tanah dan enzim papain. Hal ini dikarenakan kemampuan gluten dalam memberikan kekokohan pada mie menjadi turun akibat semakin meningkatnya jumlah tepung bungkil kacang tanah yang ditambahkan pada adonan mie. Gluten mempunyai kemampuan untuk membentuk jaringan tiga dimensi yang dapat menghambat keluarnya isi granula pada bahan. Sehingga mengakibatkan jaringan pada mie kurang kompak karena ikatan pati dan protein kurang kuat. sehingga molekul-molekul pati linier yang pendek dan tidak terikat oleh pati akan keluar dari granula dan masuk ke dalam air rebusan sehingga menyebabkan air menjadi keruh (Pratama dkk, 2014).

\section{Daya putus}

Hasil pengamatan terhadap daya putus mie kering akibat substitusi tepung bungkil kacang tanah dan penambahan getah buah pepaya kering berkisar antara $0,323-0,327 \mathrm{~N} / \mathrm{g}$.

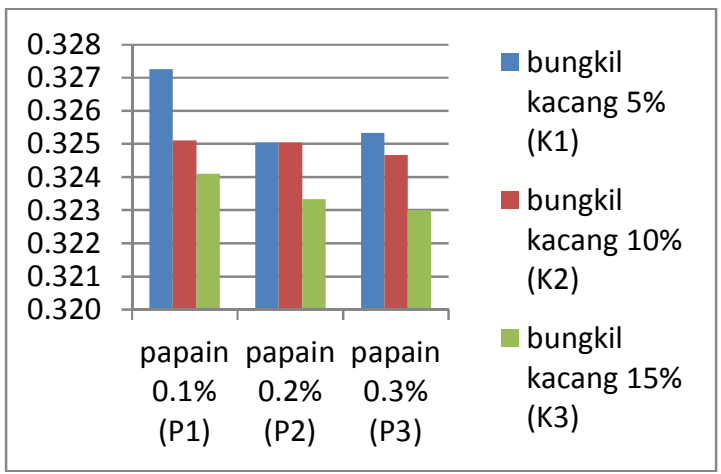

Gambar 4. Rata-rata Daya Putus Mie Kering Akibat Substitusi Tepung Bungkil Kacang Tanah 
Gambar 4 menunjukkan bahwa nilai daya putus mie kering cenderung semakin menurun seiring dengan meningkatnya penambahan tepung bungkil kacang tanah dan enzim papain. Penambahan tepung non-gluten akan mempertipis kekuatan gluten dari tepung terigu dan menggangu serta melemahkan struktur mie (Irviani dkk, 2015). Hal ini dikarenakan semakin rendah tepung terigu yang digunakan sehingga semakin rendah kadar protein gluten yang dihasilkan. Rendahnya kadar protein ini akan menyebabkan turunnya daya putus mie kering masak. Elastisitas dari mie kering masak dipengaruhi oleh gluten, di mana gluten memiliki sifat penting yaitu apabila dibasahi dan diberi perlakuan mekanis maka akan terbentuk suatu adonan yang elastis (Pratama dkk, 2014).

\section{Kadar air}

Hasil pengamatan terhadap kadar air mie kering akibat substitusi tepung bungkil kacang tanah dan penambahan getah buah pepaya kering berkisar antara 5,84\% - 10,64\%.

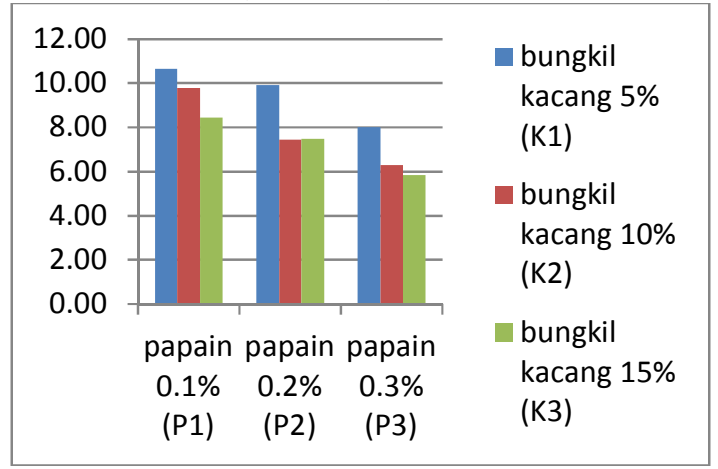

Gambar 5. Rata-rata Kadar Air Mie Kering Akibat Substitusi Tepung Bungkil Kacang Tanah

Gambar 5 menunjukkan bahwa semakin tinggi penambahan enzim papain dan substitusi tepung bungkil kacang tanah menyebabkan kadar air mie kering cenderung menurun. Mie kering dengan substitusi tepung bungkil kacang tanah sedikit, memiliki kadar air yang tinggi. Hal ini karena pada mie kering tersebut terdapat banyak tepung terigu, sehingga kadar gluten dalam mie kering cukup tinggi. Gluten yang tinggi mengakibatkan daya ikat air pada mie kering menjadi tinggi pula, gluten terjadi karena pencampuran tepung terigu dengan air (Anam dkk, 2010).

\section{Kadar abu}

Hasil pengamatan terhadap kadar abu mie kering akibat substitusi tepung bungkil kacang tanah dan penambahan getah buah pepaya kering berkisar antara $0,323 \%-0,610 \%$.

\begin{tabular}{|c|c|c|}
\hline \multicolumn{2}{|c|}{0.700} & \multirow{4}{*}{$\begin{array}{l}\text { bungkil } \\
\text { kacang 5\% } \\
\text { (K1) }\end{array}$} \\
\hline 0.600 & & \\
\hline 0.500 & & \\
\hline 0.400 & & \\
\hline 0.300 & & \multirow{3}{*}{$\begin{array}{l}\text { bungkil } \\
\text { kacang 10\% } \\
\text { (K2) }\end{array}$} \\
\hline 0.200 & & \\
\hline 0.100 & & \\
\hline \multirow[t]{4}{*}{0.000} & & \multirow{4}{*}{$\begin{array}{l}\text { bungkil } \\
\text { kacang 15\% } \\
\text { (K3) }\end{array}$} \\
\hline & papain papain papain & \\
\hline & $0.3 \%$ & \\
\hline & (P2) & \\
\hline
\end{tabular}

Gambar 6 Rata-rata Kadar Abu Mie Kering Akibat Substitusi Tepung Bungkil Kacang Tanah

Gambar 6 menunjukkan semakin tinggi substitusi tepung bungkil kacang tanah dan penambahan getah buah pepaya kering menyebabkan kadar abu mie kering semakin meningkat. Hal ini dikarenakan di dalam getah buah pepaya mengandung banyak mineral yaitu $\mathrm{Ca}$ 0,5\%, P 0,16\% dan Fe 0,04\% (Direktorat Gizi Depkes RI, 1992). Menurut Departemen Kesehatan RI, 1996 tepung bungkil kacang tanah mengandung $\mathrm{P}$ sebesar 3,35\%. Dengan begitu kadar abu mie kering akan meningkat seiring dengan penambahan getah pepaya dan tepung bungkil kacang tanah. Peningkatan kadar abu menunjukkan bertambahnya kandungan mineral pada mie kering.

\section{Kadar protein}

Hasil pengamatan terhadap kadar protein mie kering akibat substitusi tepung bungkil kacang tanah dan penambahan getah buah pepaya kering berkisar antara $14,599 \%$ $18,120 \%$. 
Jurnal Teknologi Pangan Vol. 6 No. 2 Nopember 2015

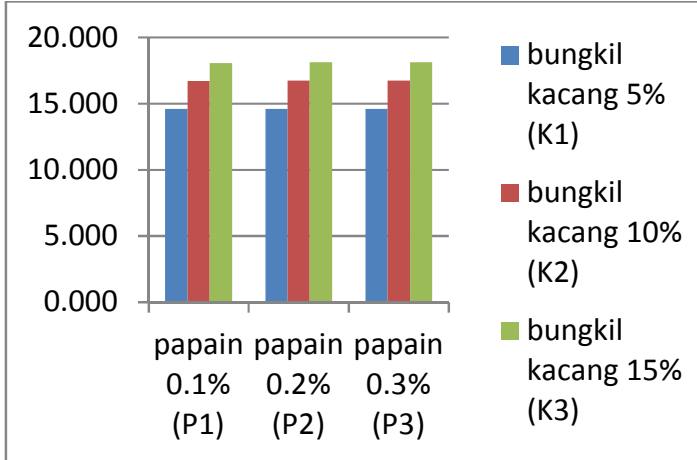

Gambar 7. Rata-rata Kadar Protein Mie Kering Akibat Substitusi Tepung Bungkil Kacang Tanah

Gambar 7 menunjukkan semakin tinggi substitusi tepung bungkil kacang tanah dan penambahan getah buah pepaya kering menyebabkan kadar protein mie kering semakin meningkat. Hal ini dikarenakan kadar protein tepung bungkil kacang tanah yang tinggi yaitu sebesar 26,4\% (Astanto dkk, 2000). Kacang tanah mengandung $22 \%$ albumin yang merupakan jenis protein yang larut dalam air (Kanetro, 2006). Getah pepaya segar mengandung $40 \pm 13 \mathrm{mg}$ protein dan $529 \pm 162$ unit protease/g getah basah (Nitsawang et al., 2006). Dengan begitu kadar protein mie kering akan meningkat seiring dengan penambahan getah pepaya dan tepung bungkil kacang tanah.

\section{Kadar lemak}

Hasil pengamatan terhadap kadar lemak mie kering akibat substitusi tepung bungkil kacang tanah dan penambahan getah buah pepaya kering berkisar antara $3,61 \%-7,08 \%$.

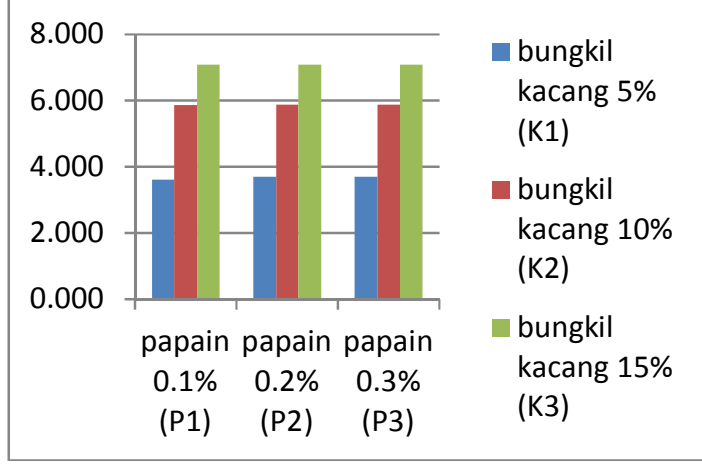

Gambar 8. Rata-rata Kadar Lemak Mie Kering Akibat Substitusi Tepung Bungkil Kacang Tanah

Gambar 8 menunjukkan semakin tinggi substitusi tepung bungkil kacang tanah dan penambahan getah buah pepaya kering menyebabkan kadar lemak mie kering semakin meningkat. Hal ini dikarenakan kadar lemak tepung bungkil kacang tanah yang tinggi yaitu sebesar 13,9\% (Muhandri, 2009) dan 0,1\% untuk lemak yang terkandung dalam getah papaya (Direktorat Gizi Depkes RI, 1992). Dengan begitu kadar lemak mie kering akan meningkat seiring dengan penambahan getah pepaya dan tepung bungkil kacang tanah.

\section{Karakteristik Organoleptik Rasa}

Rata-rata tingkat nilai kesukaan panelis terhadap rasa mie masak akibat perlakuan substitusi tepung bungkil kacang tanah dan penambahan getah buah pepaya kering berkisar antara 3,8-4,5 (menyukai - sangat menyukai).

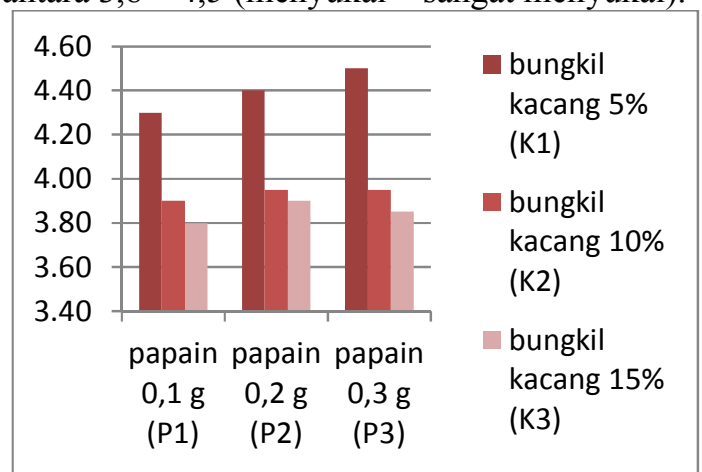

Gambar 9. Rata-rata Tingkat Kesukaan Panelis Terhadap Rasa Mie Masak Akibat Substitusi Tepung Bungkil Kacang Tanah

Gambar 9 menunjukkan bahwa semakin rendah jumlah substitusi tepung bungkil kacang tanah maka nilai kesukaan panelis pada rasa mie masak cenderung meningkat. Hal ini diduga karena rasa mie kering masak yang dihasilkan dengan semakin tingginya substitusi tepung bungkil kacang tanah kurang disukai, karena masih terasa khas dari rasa bungkil kacang tanah dan after taste yang berbeda dengan produk mie yang ada di pasaran sehingga masih belum dapat diterima oleh konsumen. Komponen penyusun rasa suatu produk ditentukan oleh besarnya kandungan protein dan lemaknya (Winarno, 2002). Bungkil kacang tanah merupakan bahan yang tinggi protein namun kadar lemaknya telah berkurang saat proses pengepresan, bahkan dapat mencapai $50 \%$ dari kadar lemak sebelum di press (Srivastava, 2011). Hal ini dapat menyebabkan berkurangnya tingkat kegurihan bungkil kacang tanah sehingga mempengaruhi rasa dari mie kering itu sendiri. 


\section{Warna}

Rata-rata tingkat nilai kesukaan panelis terhadap warna mie masak akibat perlakuan substitusi tepung bungkil kacang tanah dan penambahan getah buah pepaya kering berkisar antara 3,75 - 4,75 (menyukai - sangat menyukai).

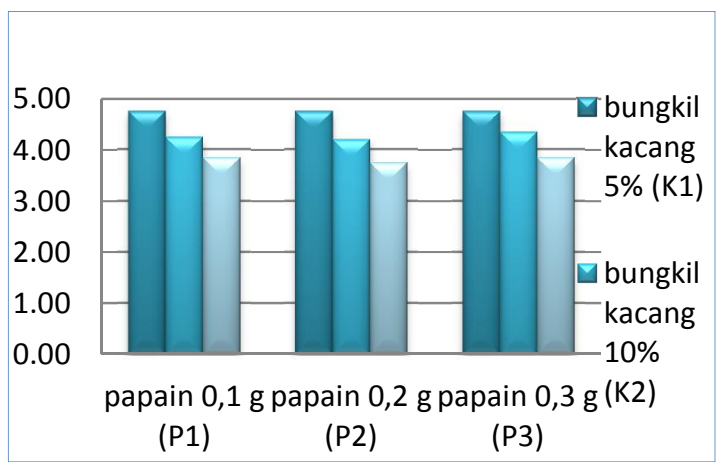

Gambar 10. Rata-rata Tingkat Kesukaan Panelis Terhadap Warna Mie Masak Akibat Substitusi Tepung Bungkil Kacang Tanah

Gambar 10. menunjukkan bahwa semakin rendah jumlah substitusi tepung bungkil kacang tanah maka nilai kesukaan panelis pada warna mie masak cenderung meningkat. Hal ini diduga karena warna mie kering masak yang dihasilkan dengan semakin tingginya substitusi tepung bungkil kacang tanah semakin gelap (coklat) dan kurang disukai serta berbeda dengan produk mie yang ada di pasaran yang berwarna kekuningan sehingga masih belum dapat diterima oleh konsumen. Warna cokelat pada mie disebabkan oleh penambahan tepung bungkil kacang tanah yang berwarna cokelat tersebut. Tepung bungkil kacang tanah telah mengalami proses pemanasan yaitu saat proses penyangraian, sementara mie juga mengalami proses pemanasan yaitu saat pengukusan dan pengeringan. Proses pemanasan dapat menyebabkan terjadinya reaksi Maillard antara gula pereduksi dari karbohidrat dengan asam amino (gugus amina primer) dari protein yang menghasilkan pembentukan warna (Irviani dkk, 2015).

\section{Aroma}

Rata-rata tingkat nilai kesukaan panelis terhadap aroma mie masak akibat perlakuan substitusi tepung bungkil kacang tanah dan penambahan getah buah pepaya kering berkisar antara 3,75-4,8 (menyukai - sangat menyukai).

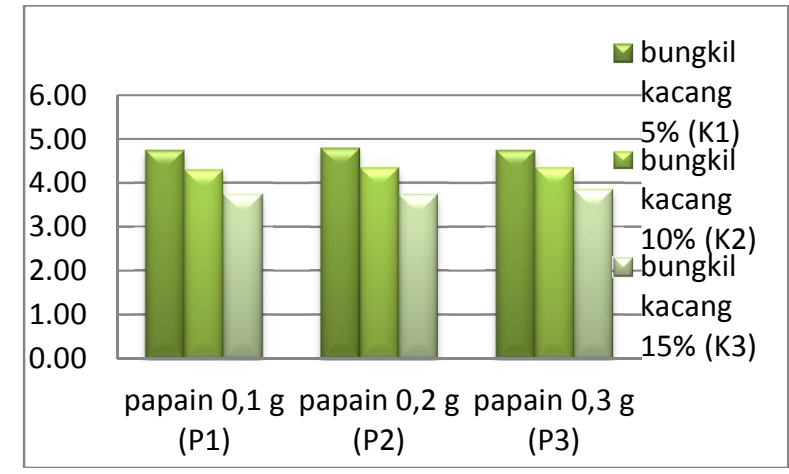

Gambar 11. Rata-rata Tingkat Kesukaan Panelis Terhadap Aroma Mie Masak Akibat Substitusi Tepung Bungkil Kacang Tanah

Gambar 11. menunjukkan bahwa semakin rendah jumlah substitusi tepung bungkil kacang tanah maka nilai kesukaan panelis pada aroma mie masak cenderung meningkat. Hal ini dikarenakan bahwa panelis kurang menyukai aroma tepung bungkil dari pada tepung terigu atau tapioka. Tepung bungkil kacang tanah memiliki aroma yang khas, sehingga aroma terasa aneh dan panelis kurang menyukainya.

\section{Tekstur}

Rata-rata tingkat nilai kesukaan panelis terhadap tektur mie masak akibat perlakuan substitusi tepung bungkil kacang tanah dan penambahan getah buah pepaya kering berkisar antara 4,1-4,85 (menyukai - sangat menyukai).

Gambar 12. menunjukkan bahwa semakin rendah jumlah substitusi tepung bungkil kacang tanah maka nilai kesukaan panelis pada tektur mie masak cenderung meningkat. Hal ini dikarenakan pada semakin banyak tepung bungkil kacang tanah yang digunakan maka semakin rendah kandungan gluten pada mie (Irviani dkk, 2015). Selain itu Enzim papain mempunyai kemampuan menguraikan ikatanikatan dalam melekul protein sehingga protein terurai menjadi polipeptida dan dipeptida. Enzim papain biasa digunakan sebagai bahan perenyah pada pembuatan kue kering seperti cracker (Silaban dkk, 2012). Sehingga nilai tekstur panelis mengalami penurunan seiring dengan penambahan enzim papain dan tepung bungkil kacang tanah. 
Jurnal Teknologi Pangan Vol. 6 No. 2 Nopember 2015

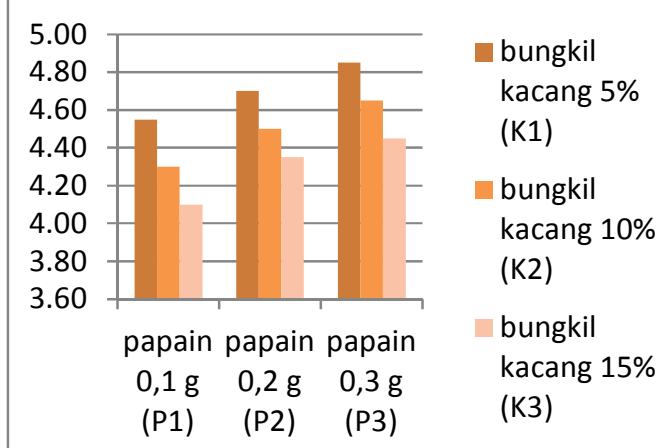

Gambar 12. Rata-rata Tingkat Kesukaan Panelis Terhadap Tekstur Mie Masak Akibat Substitusi Tepung Bungkil Kacang Tanah

\section{Perlakuan Terbaik}

Hasil penghitungan indeks efektifitas de Garmo et al., (1984) yang dimodifikasi oleh Susrini (2005) menunjukkan kombinasi perlakuan terbaik secara fisikokimia sebesar 0,1 gram dalam 100 gram getah papaya kering dan substitusi tepung bungkil kacang tanah sebesar 15\% dengan karakteristik sebagai berikut: kadar air $8,45 \%$; kadar protein $18,056 \%$; kadar abu 0,382\%; kadar lemak 7,084\%; cooking time 192 detik; cooking loss $9,353 \%$; daya putus 0,324 $\mathrm{N} / \mathrm{g}$. Uji organoleptik sebesar 0.3 gram dalam 100 gram getah papaya kering dan substitusi tepung bungkil kacang tanah sebesar 5\% dengan karakteristik sebagai berikut: warna 4,75 (sangat menyukai); rasa 4,5 (menyukai); aroma 4,75 (sangat menyukai); dan tekstur 4,85 (sangat menyukai). Uji fisikokimia dan organoleptik sebesar 0.3 gram dalam 100 gram getah papaya kering dan substitusi tepung bungkil kacang tanah sebesar 5\% dengan karakteristik sebagai berikut: kadar air 8,02\%; kadar protein 14,620\%; kadar abu 0,347\%; kadar lemak 3,706\%; cooking time 160 detik; cooking loss 5,628\%; daya putus $0,325 \mathrm{~N} / \mathrm{g}$, serta warna 4,75 (sangat menyukai); rasa 4,5 (menyukai); aroma 4,75 (sangat menyukai); dan tekstur 4,85 (sangat menyukai).

\section{KESIMPULAN DAN SARAN}

\section{Kesimpulan}

Kombinasi perlakuan terbaik secara fisikokimia sebesar 0,1 gram dalam 100 gram getah pepaya kering dan substitusi tepung bungkil kacang tanah sebesar $15 \%$ dengan karakteristik sebagai berikut: kadar air 8,45\%; kadar protein $18,056 \%$; kadar abu 0,382\%; kadar lemak 7,084\%; cooking time 192 detik; cooking loss 9,353\%; daya putus $0,324 \mathrm{~N} / \mathrm{g}$. Uji organoleptik sebesar 0.3 gram dalam 100 gram getah pepaya kering dan substitusi tepung bungkil kacang tanah sebesar 5\% dengan karakteristik sebagai berikut: warna 4,75 (sangat menyukai); rasa 4,5 (menyukai); aroma 4,75 (sangat menyukai); dan tekstur 4,85 (sangat menyukai). Uji fisikokimia dan organoleptik sebesar 0.3 gram dalam 100 gram getah pepaya kering dan substitusi tepung bungkil kacang tanah sebesar 5\% dengan karakteristik sebagai berikut: kadar air 8,02\%; kadar protein $14,620 \%$; kadar abu 0,347\%; kadar lemak 3,706\%; cooking time 160 detik; cooking loss 5,628\%; daya putus $0,325 \mathrm{~N} / \mathrm{g}$, serta warna 4,75 (sangat menyukai); rasa 4,5 (menyukai); aroma 4,75 (sangat menyukai); dan tekstur 4,85 (sangat menyukai).

\section{Saran}

Demi kesempurnaan dan pengembangan hasil penelitian penambahan getah pepaya kering dan substitusi tepung bungkil kacang tanah terhadap kualitas fisikokimia dan organoleptik mie kering, maka disarankan:

1. Adanya penelitian lanjutan tentang daya simpan mie kering bungkil kacang tanah.

2. Adanya penelitian tentang kualitas bungkil kacang yang terbaik serta daya simpannya.

3. Adanya penelitian lanjutan mengenai pengolahan bungkil kacang tanah dan getah papaya kering menjadi produk lainnya yang dapat memberikan nilai guna bungkil kacang tanah

\section{DAFTAR PUSTAKA}

Anam. C dan Sri, H. 2010. Mi Kering Waluh (Cucurbita moschata) Dengan Antioksidan Dan Pewarna Alami. Jurnal Caraka Tani Vol 25 (1)

AOAC. 1990. Official Methods of Analysis. Association of Official Analysis Chemistry. Wanghiston

Astanto, K., Achmad, W. dan Sunardi. 2000. Kacang Tanah. Balai Penelitian Tanaman Pangan. Malang

De Garmo, E.D., Sulivan W.G. dan Canada J.R. 1984. Engineering Economy. MacMilan Publishing Company. New York.

Direktorat Gizi Departemen Kesehatan RI. 1992. Daftar Komposisi Bahan Makanan. Bharata. Jakarta 
1996. Daftar Komposisi Bahan Makanan. Bhratara Karya Aksar. Jakarta

Irviani. L.I dan Nisa, F.C. 2015. Kualitas Mie Kering Tersubsitusi Mocaf. Jurnal Pangan dan Agroindustri 3 (1): 215-225

Kanetro. B dan Setyo, H. 2006. Ragam Produk Olahan Kacang Kacangan. Yogyakarta: Unmawa Press

Muhandri, T. dan Subarna. 2009. Pengaruh Kadar Air, $\mathrm{NaCl}$ dan Jumlah Passing Terhadap Karakteristik Reologi Mi Jagung. Jurnal Teknologi dan Industri Pangan 20 (1)

Nitsawang S, Hatti-Kaul R, dan Kanasawud P. 2006. Purification of papain from Carica papaya Latex: aqueous two-phase extraction versus two-step salt precipitation. Enzyme Microb Tech 39:1103-1107.

DOI:10.1016/j.enzmictec.2006.02.013

Oh, N.H., Seib, D.A., Deyoe C.W. dan Ward A.B. 1985. The Surface Firmness of Cooked Noodles From Soft and Hard Wheat Flours. Cereal chemistry 62 (6): 431-436

Pratama. I.A, dan Nisa F.C. 2014. Formulasi Mie Kering Dengan Subsitusi Tepung Kimpul (Xanthosoma sagittifolium) Dan Penambahan Tepung Kacang Hijau (Phaseolus radiatus L.). Jurnal Pangan Dan Agroindustri 2 (4): 101-112

Romlah, T. 1997. Teori dan Praktek Bimbing Kelompok. Jakarta: P2LPTK.

Silaban. R, Freddy T.M.P dan Rahmadani. 2012. Pemanfaatan Enzim Papain Getah Buah Pepaya. Laporan Hasil Penelitian Dosen Guru Besar Dan Doktor Sesuai Keahlian Bidang Ilmu Biokimia/Bioteknologi

Srivastava. P dan Rishabha, M. 2011. Sources of Pectin, Extraction and Its Application in Pharmaceutical Industry-An Overview. Indian Journal of Natural Products and Resources 2: 10-18

Sudarmadji, S. dkk. 1997. Prosedur Analisis Untuk Bahan Makanan dan Pertanian. Edisi ke tiga, Liberty, Yokyakarta.

Susrini. 2005. Indeks Efektivitas. Fakultas Peternakan. Universitas Brawijaya. Malang

Widiatmoko, R.B dan Teti, E. 2015. Karakteristik Mie Kering Berbasis Tepung Ubi Jalar. Jurnal Pangan dan Agroindustri 3 (4): 1386-1392
Winarno. 2002. Kimia Pangan dan Gizi. Gramedia. Jakarta 